УДК 625.42:625.143

\title{
УМОВИ РОБОТИ СПОЛУЧЕННЯ «ПДОШВА РЕЙКИ - РЕБОРДА ПІДКЛАДКИ» СКРІПЛЕННЯ “МЕТРО” В РЕЖИМІ ЗМАЩЕННЯ
}

\author{
К-т техн. наук О.О.Овчинніков
}

\section{УСЛОВИЯ РАБОТЫ СОПРЯЖЕНИЯ «ПОДОШВА РЕЛЬСА - РЕБОРДА ПОДКЛАДКИ» СКРЕПЛЕНИЯ “МЕТРО” В РЕЖИМЕ СМАЗЫВАНИЯ}

\author{
К-т техн. наук А.А.Овчинников
}

\section{THE WORKING CONDITIONS OF THE CONJUGATION "RAIL BASE EDGE - BASEPLATE FLANGE" FASTENING "METRO" IN THE MODE OF LUBRICATION}

\section{Cand. of techn. sciences O.Ovchinnicov}

У статті розглянуті питання, пов'язані з умовами роботи сполучення «кромка підошви рейки - реборда підкладки» підрейкових підкладок типу «Метро» у режимі граничного змащення. На основі спостережень та аналізу раніше проведених досліджень, вивчено та визначено прочеси, щзо протікають у граничній системі «метал - мастило метал». Розглянуто основні функиіональні призначення змашувального шару (третьої фази) y сполученні «кромка підошви рейки - реборда підкладки». На основі отриманих даних сформовано ряд висновків, які дозволяють визначити покажчики критичної товщчни шару мастила.

Ключові слова: мастило, зношення, кромка підошви рейки, реборда підкладки

В статье рассмотрены вопросы, связанные с условиями работы сопряжения «кромка подошвы рельса - реборда подкладки» подрельсовых подкладок типа «Метро» в режиме граничной смазки. На основании наблюдений и анализа ранее проведенных исследований изучены и определены прочессы, которые протекают в граничной системе «металл смазка - металл». Рассмотрены основные функциональные назначения смазывающего слоя (третьей фазы) в сопряжении «кромка подошвы рельса - реборда подкладки». На основании полученных данных сформирован ряд выводов, которые позволяют определить показатели критической толщины слоя смазки.

Ключевые слова: смазка, износ, кромка подошвы рельса, реборда подкладки.

The article describes the problem connecting with working conditions of the conjugation "rail base edge - baseplate flange" of under-rail baseplates "Metro" type in the thin-film lubrication mode. Based on monitoring and analysis of earlier carried out researches it has been studied and determined the processes which take place in the liquid-film system "metal lubrication - metal". The main functional purposes of the lubrication layer (the third phase) in the conjugation "rail base edge - baseplate flange" have been examined. Under obtained data it has been formulated the number of conclusions which allow to determine the value of critical thickness of lubrication layer:

1) lubrication layers shield the fields of force of friction surfaces due to the adhesive component of the friction coefficient decreases;

2) active components of the lubrication layer while absorbing on the friction surfaces divide them with a thin film consequently the influence of the mechanical friction decreases that leads to wear out decreasing;

3) shifting deformation is localizing in the lubrication layer and it prevents destruction of subjacent layers and provides rather low friction costs.

Based on the analized data it has been formulated one of the principal conclusion that is the critical thickness of liquid-film on the friction surface is the limit which provides minimum of 
friction and wearing out of friction surfaces may be expected minimal, because the action area of force field is limited by this thickness.

Keywords: railway, underground, lining's rebord wear, friction, frettage-corrosion, greasing.

Особливу небезпеку для метрополітенів, причому незрівнянно більшу, ніж для магістральних залізниць, являє собою уширення колії у кривих ділянках внаслідок зношення упорних реборд підрейкових підкладок типу «Метро» на зовнішній рейковій нитці. Причиною цього $\epsilon$ конструктивні особливості скріплення та великі навантаження ударного характеру, вплив тертя за наявності абразивних продуктів зношення елементів колії та забруднення тунелю, що виникають при проходженні поїздів. У зв'язку з цим особливої актуальності для безпеки руху поїздів набуває проблема забезпечення уповільнення зношення упорних реборд підрейкових підкладок типу «Метро».

Більшість сполучень у машинах та механізмах за наявності рідкого змащувального середовища або пластичних матеріалів між поверхнями тертя працюють у режимі граничного тертя. Таке тертя характеризується наявністю тонкого змащувального середовища, товщина якого визначається границею дії силового поля поверхонь тертя (природою поверхонь тертя) на змащувальний матеріал. Вивченню механізму граничного тертя та процесів, що протікають у системі «метал - мастило метал», присвячено багато науководослідних робіт, зокрема [1, 2, 3, 4 та ін.]. Їх аналіз показує, що механізм граничного тертя характеризують такі основні процеси:

механічна (пружно-пластична) взаємодія металів та їх окисних шарів на поверхнях контакту гребенів геометричного профілю в ювенільних умовах доторкання та через змащувальний шар;

процеси ван-дер-ваальсової адсорбції орієнтаційної чи дисперсійної природи, що визначають структуру та механічні властивості змащувального матеріалу залежно від кількості мастила (товщини шару), температури, тиску та швидкості ковзання;

процеси

молекулярних когезійних взаємодій у вигляді дипольних, лондонівських, водневих або хімічних зв'язків, що виникають між молекулами та ускладнених двостороннім впливом на них полів поверхонь тертя;

- $\quad$ хімічні реакції молекул мастила

та металу.

Bci ці процеси протікають 3 переважним розвитком одного чи декількох 3 них. Треба зауважити, що перелічені процеси режиму граничного змащення відносяться до такого змащувального матеріалу, в якому відсутні компоненти, властиві експлуатаційним умовам роботи пар тертя (продукти зносу та окиснення, забруднення та ін.).

Вивчення вказаних процесів насамкінець спрямоване на зменшення витрат на тертя, зниження зношення $[1,6,8$ та ін.]. Розглянемо основні функціональні призначення змащувального шару (третьої фази) у сполученні:

1) змащувальні шари екранують силові поля поверхонь тертя, завдяки чому знижується адгезійна складова коефіцієнта тертя.

2) активні компоненти змащувального шару, адсорбуючись на поверхні тертя, розділяють їх тонким шаром, в результаті чого механічний вплив пар тертя зменшується, що приводить до зниження зносу.

3) зсувні деформації локалізуються у змащувальному шарі, що запобігає руйнуванню нижче розташованих шарів, та при цьому забезпечуються відносно малі витрати на тертя.

Якщо розглядати граничні шари різної товщини за інших рівних умов, то, згідно 3 численними експериментальними дослідженнями, їх склад є досить різним, бо він визначається не тільки тиском, але й геометричною формою (топографією). При цьому чим тоншим $\epsilon$ шар, тим вищою $\epsilon$ його пружність та нижчою пластичність. Таке явище пояснюється тим, що молекулярні ряди змащувального шару мають різну енергію зв'язку 3 поверхнею тертя, яка 
убуває вздовж іiі осі, нормальної до поверхні тертя, тобто одне явище (зовнішне навантаження системи) породжує інше явище (зростання пружності змащувального шару).

Таке явище підкреслює двохосьову анізотропію фізичних властивостей граничного шару, тому постає важливе питання про те, за якої товщині граничного шару та яких умов наступає явище зсуву молекулярних рядів.

Згідно експериментальних досліджень [4] встановлено, що по мірі збільшення товщини змащувального шару (мультимолекулярного), що утворює правильну кристалічну структуру, зв'язок між іiі димерними рядками у напрямку від поверхні тертя слабшає, що пояснюється послабленням поля поверхні тертя, та наступає фазовий перехід у мастильній плівці від твердокристалічного до рідкокристалічного стану.

Такий перехід відноситься до граничного режиму виникнення гідростатичного тертя. Дослідження показують, що в цьому переході спостерігається мінімум тертя, тобто виникають факти ламінарного ковзання шарів змащувальної плівки. А.С. Ахматов [2] припускає, що такий перехід супроводжується неметалічним механізмом, мінімум тертя, що спостерігається в цьому режимі, відображається за допомогою діаграми Штрібека [3].

Припускаємо, що змащувальний шар виражається не тільки за допомогою раніше викладених передумов, але й виконує захисні функції щодо поверхонь тертя. Агресивні дії, пов'язані 3 хімічними реакціями, та подібні процеси сприяють виконанню захисної функції, тобто домінує процес фізичної адсорбції та, як результат, домінують захисні функції змащувального шару.

Найбільший мінус в прикладному значенні, з позиції зниження тертя та зносу, являє собою граничний режим, поява гідродинамічного тертя. Розглянемо фізичні процеси, що супроводжують його.

Згідно із висновками У.Гарді $[9,10]$, зменшення коефіцієнта статичного тертя зростає зі збільшенням товщини шару до деякої граничної величини та після цього залишається постійною. Сила статичного тертя за інших рівних умов є функцією двох змінних - тиску та товщини шару (рис. 1).

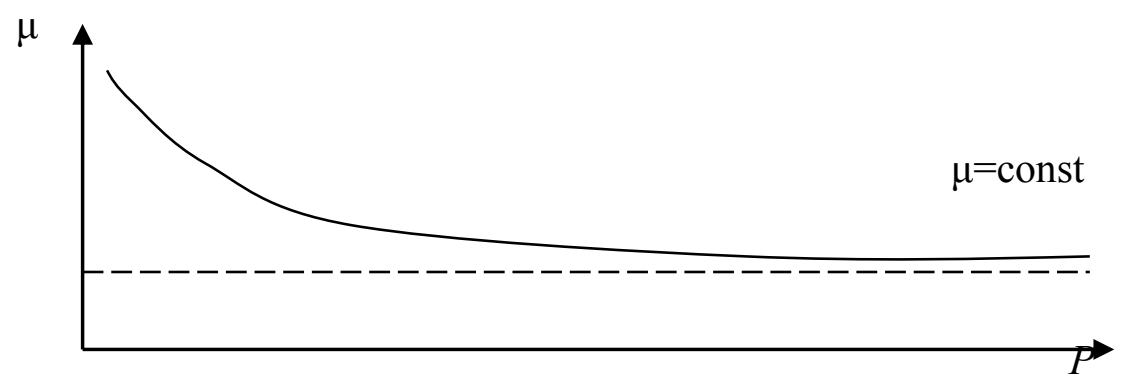

Рисунок - 1 Залежність коефіцієнта статичного тертя від тиску в умовах граничного змащення

Ці дані дозволяють зробити висновок, що сполучення пари тертя «кромка підошви рейки - упорна реборда підкладки» в режимі граничного змащення, за деякої товщини змащувальної плівки, володіють пружністю, яку можна вважати, залежно від зовнішнього навантаження, величиною сталою. Такий факт можна підтвердити тим, що за збільшення тиску зустрічне проникнення молекулярних ланок у міжмолекулярний простір (канали) супроводжується збільшенням потенційної енергії відштовхування атомних груп та шарів у цілому. Для гранично великих тисків товщина змащувальної плівки має порядок величин десятих ангстрема, тобто за певної товщини змащувального шару на поверхні тертя він стає практично нестисливим. Такий факт підтверджують і експериментальні дослідження зі змінення електричного опору [5]. За перевищення критичної товщини абсорбованого шару молекул присадки електричний опір стає дуже високим. 
Одним із ключових питань умов роботи пар тертя в режимі граничного змащення для забезпечення низького коефіцієнта тертя та мінімального зносу $\epsilon$ товщина граничного змащувального шару. Згідно експериментальних досліджень його величина для високомолекулярних насичених жирних кислот знаходиться у межах 0,05 - 0,1мк. Ці дані підтверджено шляхом вимірювання зміни затухання коливань нахильного маятника [2, 3, 4].

Згідно теоретичних

та

експериментальних досліджень, пов'язаних 3 вивченням пружно-пластичних властивостей граничних змащувальних шарів полярних молекул на поверхні металу [2], встановлено, що вони мають аномалії механічних властивостей та, в першу чергу, анізотропні властивості. Останні яскраво проявляються в зміненні модулів однобічного стиснення та зсуву за товщиною граничного змащувального шару [2].

На основі вище вказаного можна дійти висновків:

1) на поверхнях тертя формується змащувальний шар, який складається, головним чином, 3 адсорбованих молекул присадки, якщо їх концентрація дозволяе досягати моменту насичення, тобто «дозрівання» такого шару;

2) процес формування змащувального шару зумовлений адсорбцією, яка залежить від області дії силового поля поверхонь тертя та дипольного моменту молекул присадки, i, як результат такого процесу, поверхня тертя вкрита адсорбційним шаром полярних молекул;

3) фізичні властивості граничного шару змащування, сформованого на поверхні тертя, відрізняються родом аномальних явищ, до числа яких відноситься анізотропія пружних властивостей за товщиною. Внаслідок збільшення зовнішнього навантаження сполучення (пари тертя) у певний момент часу переходить до зони кристалічної товщини, коли змащувальний шар володіє властивостями твердого тіла.

Такий висновок поки що не задовольняє температурний фактор, дія якого на фазові переходи у граничному шарі може бути також суттєвою, а в деякому діапазоні - значною.

Загальну структуру змащувального шару на поверхні тертя, сформованого 3 молекул протизносної присадки, можна представити схематично (рис. 2) [7].



Рисунок - 2 Схема структури граничного змащувального шару на поверхні металу: А - полікристалічна поверхня металу; Б - полікристалічна поверхнева зона граничного шару; В - його монокристалічна зона

Ключова роль у такій схемі, з точки зору зносу та зниження тертя, належить границі твердокристалічної та пружнов'язкої зон.

Висновки:
1) критична товщина граничного шару на поверхні тертя є границею, при якій спостерігається мінімум тертя, а знос поверхонь слід очікувати мінімальним, 
оскільки область дії силового поля поверхні тертя обмежена цією товщиною;

2) за критичної товщини граничного шару мастило володіє властивостями твердого тіла і коефіцієнт статичного тертя не залежить від тиску, тобто молекули присадки ще знаходяться під дією силового поля поверхні тертя та, завдяки властивостям критичної концентрації адсорбції молекул присадки, знаходяться у найбільш сприятливому варіанті пакування. Отже, фізичні властивості такого шару можна прийняти, 3 певним допущенням, величиною сталою.

\section{Список використаних джерел}

1. Алябьев А.Я. Методы защиты деталей от фреттинг-коррозии / А.Я. Алябьев // Надежность и долговечность авиационных газотурбинных двигателей: сб. науч. тр. - Киев: изд-во КИИГА. - Вып. 1. - 1971. - С. 58-62.

2. Ахматов А.С. Молекулярная физика граничного трения / А.С.Ахматов - М.: Физматгиз, 1963. - $472 \mathrm{c.}$

3. Голего Н.Л. Фреттинг-коррозия металлов / Н.Л. Голего, А.Я. Алябьев, В.В. Шевеля - Киев: Техника, 1974. - 272 с.

4. Лысиков Е.Н. Надмолекулярные структуры жидких смазочных сред и их влияние на износ технических систем / Е.Н. Лысиков, В.Б.Косолапов, С.В. Воронин. Харьков, ЭДЭНА, 2009. - 274 с.

5. Повышение ресурса технических систем путем использования электрических и магнитных полей: моногр. / Е.Е. Александров, И.А. Кравец, Е.Н. Лысиков и др. - Харьков: НТУ «ХПИ», 2006. - 544 с.

6. Сухое и граничное трение. Фрикционные материалы: труды третьей всесоюзной конференции по трению и износу в машинах. - М.:Изд. АН СССР, 1960. - 303 с.

7. Гаркунов Д.Н. Триботехника / Д.Н. Гаркунов // - 2-е изд., переб. и доп. - М.: Машиностроение, 1989. - 328 с.

8. Barten A. Passungsrost bzw. Peiboxidatoin - besondere verseheibprobleme der maschinenschaden. Heft 3/4, - 1964

9. W.B. Hardy, Collected Scientifick Papers, Cambridge. -1936.

10. W.B. Hardy, J. Birkumshay, Proc. Roy. Soc. - A108. - 1 (1925).

Рецензент д-р техн. наук, професор О.В.Лаврухін

Овчинніков Олександр Олександрович, канд. техн. наук, доиент кафедри колії та колійного господарства Української державної академії залізничного транспорту, тел. +38(057)7301059.

Ovchinnikov Olexandr, cand. techn. sciences, associate professor of Department "Track and Track Maintenance”, Ukrainian State Academy of Railway Transport, tel +38(057)7301059. 